DOI https://doi.org/10.36059/978-966-397-108-7/82-104

\title{
SECURITY OF URBAN POPULATION SAFETY \\ IN THE CONDITIONS OF CRISIS OF THE LAW \\ ENFORCEMENT SYSTEM IN UKRAINE IN 1917-1920
}

\section{Popov V. Z.}

\section{INTRODUCTION}

Life safety is one of the basic human needs. Ensuring this security has always been one of the most important functions of the state. Protection by any means of oneself, one's loved ones, one's property against unlawful encroachments by any criminal law is not considered a crime. The ability of a person, society, state to guarantee order and peace in any conditions is relevant before and today. But order and peace are especially important in conditions of wars and revolutions, when the foundations of statehood are undermined, legal norms lose their force, and law enforcement structures broken up.

Any social transformation leads, among other changes, either to the restructuring of the administrative apparatus, or to its resolute breakdown and replacement of the previous authorities. In this case, the qualitative composition of the state apparatus inevitably deteriorates, and as a result, its professional level is reduced. The society reacts to the incompetence of the new government with a surge of initiative measures, which are expressed in the organization of structures that take on many of the state functions, especially necessity to provide the vital social needs. These include the need for security.

In the conditions of a permanent crisis of power that occurred in Russia since February 1917, an administrative and legal vacuum was formed, and various antisocial elements tried to take advantage of. Even the presence of certain state structures did not relieve the population of the need to independently solve management tasks. In the period of the Ukrainian national democratic revolution of 1917-1920 active hostilities and frequent changes of government took place on the territory of our country, numerous illegal armed groups arose, and the threat for ordinary citizens was greater than ever. 
If we take a look at the physical threat to ordinary citizens, under the conditions of revolution and civil war, it consisted primarily in periodically renewed battles in each city, accompanied by artillery shelling and rifle-and-machine-gun fire. Secondly, each new government sought out among the urban population real or imaginary enemies, who were often threatened with immediate punishments. In the initial period of the revolution the crowds of soldiers - deserters or demobilized- were posing a grave danger. Third, the usual, traditional criminality continued antisocial actions. This process began in between the summer and autumn of 1917, when the official law enforcement authorities lost the ability to fully realize their functions. The state function to control the law and order enforcement was significantly weakened. Part of the antisocial elements was united in groups, and started almost uncontrolled robberies and looting.

So the period of revolution and civil war set the task before the residents of cities and villages of Ukraine - as much as possible to protect themselves from anarchy, which was accompanied by hooliganism, banditry, looting and murder. In this situation, the only opportunity to stabilize the situation often was the initiative of individual citizens and their voluntary associations to create self-organized groups, whose main task was to stop anyone's encroachment on the life and property of a certain kind of people. This task was accomplished through self-protection, which was called differently, but performed almost identical work.

\section{Individual Protection Organization}

"Kievskaya Mysl" newspaper in November 1917 informed its readers of the increased danger of being a victim of a criminal offense, it also posted about the dozens of daily robberies, attacks and raids. The danger of being robbed lurked everywhere. For example, a doctor returning from a visit to the patient was undressed at the main entrance near to his apartment ${ }^{1}$.

According to one of the contemporaries of the events, D.I. Doroshenko, in the autumn of 1917, the police in Chernigov was bad, the population was not protected by anyone ${ }^{2}$. In other cities, the situation was not better. Many random unprofessional people got into the ranks of

\footnotetext{
${ }^{1}$ Киевская мысль. № 156. 29 ноября 1917 г.

2 Революция на Украине по мемуарам белых. Киев, Политиздат, 1990 г. - С. 73.
} 
the police, allowing lawless actions even with the Reds, even with the Whites. In addition to the systemic crisis of law enforcement agencies, two factors led to the rise in crime. First, it was more and more widespread alcoholism. "The nightmare of impending drunkenness, drunken bacchanalias, robberies and shooting on the city's streets and in the vicinity has been growing more and more"3. Secondly, the population had a huge amount of weapons. Thirdly, the criminal situation was exacerbated by the returns of deserters from the front, and the demobilization of the army in the autumn of 1917. Peasants with horror were awaiting the invasion of soldiers gangs. The trains were not able to transport the whole mass of disorganized soldiers, and many of them walked crowded along the snow-covered fields, stopping for the night in villages, plundering peasants and landowners, were drinking and starting indiscriminate shooting in the air $^{4}$. Crimes were committed at any time of the day, establishments and individuals also were robbed.

The social identity of the robbers could be noticed clearly. Their main sign, and at the same time disguise, was a military uniform. The reality of the revolutionary days was open looting from those who, it would seem, should ensure order. Shops in the winter of 1917-1918 subjected to robbery under the guise of confiscation, with the presentation of orders from the military revolutionary committees.

Unauthorized searches, looked more like ordinary robberies, were so massive that there were issued a special order from the General Secretary of the Interior of the Central Rada: "In recent days, unknown persons, without any authority, are illegally affording themselves to stop citizens on the streets to check their documents, are conducting searches and arrests. Those who illegitimately conduct searches should be detained and held accountable to the fullest extent of the law".

Before the coming of the Germans, "gangs of robbers" were organized, performing night robberies in the townsfolk, attacking houses and their inhabitants with weapons. "The unfortunate man in the street, disarmed by the Bolsheviks, was deprived of the most elementary means of self-defense" ${ }^{, 6}$. Under the hetman, when refugees ran into Ukraine,

\footnotetext{
${ }^{3}$ Вольный Юг (Севастополь). № 31.4 января 1918 г.

${ }^{4}$ Державний архів Російської Федерації (ДАРФ), ф. 5881, оп. 2, спр. 296, арк. 4.

5 Українська Центральна Рада. Документи і матеріали у двох томах. Том 1. 4 березня - 9 грудня 1917 р. К.: Наукова думка, 1996. - С. 384.

61918 год на Украине. Серия «Россия забытая и неизвестная. Белое движение». М.: Центрполиграф, 2001. - С. 35.
} 
gangs of robbers appeared in the border forests ${ }^{7}$. The activity of the criminal element got extremely strengthened in Odessa during the interventionists. "The night did not pass without a few murders and dozens of robberies" ${ }^{\prime 2}$. In December 1918, a gunfire began in the city between unknown gangsters who were shooting at one of the city hotels from two sides, and the hotel itself, which "responded with a machine gun", In the spring 1919, night robbing and killing of passersby were taking place even on central streets. In the middle of the day, so-called "raids" were made on banks and jewelry stores. The gangsters drove up to a bank or a shop, entered there, and after threatening with weapons and firing at those who resisted, quickly took away the valuables, and just as quickly escaped $^{10}$.

In August 1919, the Reds, volunteers, and the army of the UPR appeared at the same time in the vicinity of Kiev. Opposers stayed on the outskirts of Kiev, there was no one in the center, and "the criminal elements rushed to rob". There were shouts in the streets calling for help ${ }^{11}$. At the beginning of 1920, when the Red Army was approaching, robbery gangs, that were attacking passersby, became active again in Odessa $^{12}$. However, the arrival of the Reds did not mean an immediate establishment of the order and calm. In the spring of 1920, gangs of robbers "flew into the houses under the guise of working patrols checking the activities of the house committees", or were hiding behind the name of the emergency commission (Cheka). "Often it was impossible to make out who had committed the robbery: the Cheka disguised as workers or raiders, the raiders disguised as the Cheka or workers, or the workers themselves, tempted by a large profit"13.

The population was almost accustomed to the frequent robberies, but "it was quivering and afraid of the Cheka". The robbers thanked God that "fortunately, they were ordinary robbers, and not messengers

\footnotetext{
${ }^{7}$ Из путевых заметок беженца. Кн. Е.Н. Трубецкого // Архив русской революции. Том 18. Берлин, издательство «Слово», 1926 г. - С. 139.

8 Якушкин Е. Французская интервенция на Юге. 1918-1919. М.-Л.: Государственное издательство, 1929. - С. 37.

${ }_{9}^{9}$ Центральний державний військовий архів Російської Федерації (ЦДВА), ф. 1410, оп. 1, спр. 13, арк. 9 зв.

${ }^{10}$ ДАРФ, ф. 5881, оп. 2, спр. 435, арк. 8.

${ }^{11}$ Красная смута: сб. ист. лит. произв. М.: Содружество «Посев», 2011. - С. 188.

12 Тэффи Н.А. Житье-бытье: Рассказы. Воспоминания. - М.: Политиздат, 1991. - С. 331.

${ }^{13}$ ДАРФ, ф. 5881, оп. 1, спр. 704, арк. 11.
} 
from an emergency commission"14. V.I. Vernadsky wrote in his diary at the beginning of March 1918 that the population of Poltava expects that "they will soon kill the bourgeoisie class, and the servants too, as they are for the "bourgeoisie"15. "Decently dressed" men and women were insulted on the streets, had been taken off their hats and broken their umbrellas snatched from their hands ${ }^{16}$. In August of the same year, Vernadsky reported that "armed gangs, either Bolsheviks or rebels against Germans, were robbing villages and landowner houses"17.

In Kharkov, in the night time, the shooting was usual. "Through the rare gaps between the gusts of wind, the close and distant shots from rifles slam." Everyone who had a weapon is shooting - guards shot to encourage themselves, and robbers "fired because of their criminal trade" 18 .

The first reaction of the inhabitants to the threat of their life was the desire to have a personal weapons. "Just imagine - the most lousy revolver costs two hundred rubles! Cartridges for it - a half ruble! And the Browning or the Parabellums - those are unreachable - not less than four hundreds! What a poor person can do?" - "Why does a poor person need a revolver?" - "Well, how can ... Whose life is not precious! Yes, and it is desirable to save money too" 19 .

The tool of rescue for casual witnesses of street fights, of course, was not the use of weapons, but usual getaway. The standard way to protect themselves was hiding in the basements of high-rise buildings. For example, in Odessa, the inhabitants of the upper floors went down, many were hiding in the cellars ${ }^{20}$. With the approach of the Bolsheviks to Kiev in January 1918, when systematic shelling began, the frightened population rushed into the basements, and only a few, "maintaining

14 Там само, арк. 13.

15 Вибрані наукові праці академіка В.І. Вернадського. Том 9. В.І. Вернадський. Щоденники (1917-1921). К.: НАНУ, 2011. - С. 54.

${ }^{16}$ Центральний державний архів громадських об’єднань України (ЦДАГО), ф. 5, оп. 1, спр. 21, арк. 28.

${ }^{17}$ Вернадський В.І. Вказ. тв. - С. 119.

18 Слободской А. Это было... (на Украине и в Крыму в 1918-1920 гг.). Харьков, «Пролетарий», 1926. - C. 24

${ }^{19}$ Киевская мысль. № 104, 26 сентября 1917 г. арк. 44.

20 Російський державний архів соціально-політичної історії (РДАСПI), ф. 71, оп. 34, спр. 102а, 
complete self-control", did not move from their places ${ }^{21}$. Some citizens of Kiev used to cover the windows with a mattresses ${ }^{22}$.

Yekaterinoslav teacher G. Igrenev recalled that with the approach of the Makhnovists in the winter of 1918-1919 all the inhabitants of the house, in the absence of a basement, gathered in a seemingly safer entrance of the ground floor. When the Makhnovists settled in his apartment, at night they allowed to lock the door between the dining room to the back rooms ${ }^{23}$.

In Kharkov, when White army soldiers were on the deserted streets, sometimes there appeared a "lonely figure of a belated philistine", who hastily made his way to his home. "Through the rare gaps between the gusts of wind", there were slamming close and distant rifle shots. After each close shot, the belated pedestrian, "running without looking back", overcame some distance "to the nearest impressive object to hide". Having stopped, the pedestrian took a breath, and, having waited a moment, he darted off and ran on ${ }^{24}$.

It was possible to hide not only in homes and apartments. Familiar with V.I. Vernadsky, G.Y. Zhukovsky, with his wife and children escaped to the forest where they were hiding during six days, "as officers and bourgeois men were beaten between the leaving of the Red Army and the coming of the Germans" 25 .

In desperation, people found absolutely exotic places for salvation. One of the former generals, being already old age, was struggling with the bandits who attacked his house, first he tried to shoot back through the door, then he hid in a crypt located near to the house, where he lay down in one of the coffins right on the skeleton, being dressed only in his underwear. The gangsters did not want to give up, and began to look for a general with flashlights. Entered the crypt, they opened the lid of the coffin. When the general, all in white, got up, the gangsters fled in horror ${ }^{26}$.

Without waiting for their turn to be arrested, many people in Kiev did not sleep at home, others did not come home at all. One of Kiev

\footnotetext{
211918 год на Украине. - С. 30.

22 Очерки жизни в Киеве в 1919-1920 гг. Л. Л-ой // Архив русской революции. М.: ТерраПолитиздат, 1991. т. 3. - С. 219.

${ }^{23}$ Игренев Г. Екатеринославские воспоминания (август 1918-июнь 1919 г.) // Архив русской революции. Изданный Г.В. Гессеном. М.: Терра-Политиздат, 1991. т. 3. - С. 238.

${ }^{24}$ Слободской А. Указ. соч. - С. 24.

${ }^{25}$ Вернадский В.И. Указ. соч. - С. 94.

${ }^{26}$ ГАРФ, ф. 5881, оп. 2, д. 296, л. 9.
} 
student's acquaintances, when returning home, was getting off the cab behind his house's corner, then, looking around, was moving to his own door. He was afraid of an ambush. Another friend, a relative of the hetman, was hiding in different houses and apartments during four months. When she caught a cold and soon died, she was even buried under an assumed name. Anyway, there were several acquaintances attended her funeral ${ }^{27}$.

In Sevastopol, during Wrangel's ruling, the streets were empty, despite not yet late time. "It seems like an usual man imposed martial law on himself", people did not leave the house after nine o'clock in the evening, fearing to be robbed or killed ${ }^{28}$.

Under the conditions of social confrontation, disguise was a characteristic way for previously privileged strata of society to protect themselves from reprisals. In 1917, officer Vladimirov, getting to his home on the roof of the train, noticed that there was no a single officer among the mass of soldiers. Apparently, all the officers, like him, dressed on soldier's overcoats, and for a while became "comrades" 29.

The word "bourgeois" meant "any intelligent person who wore a decent dress". It was dangerous to walk outside wearing on a bowler hat or hat. The audience had redressed "in an inconspicuous dress and was disgusted". People from the society "took out terrible worn coats from somewhere, and put on their heads caps". To stay dressed as a commoner was considered necessary for personal safety ${ }^{30}$. In 1919 in Kiev, under the Bolsheviks, all the men were dressed uniformly. "high boots and protective color were prevailed". The people's look has became new and unusual. "Something happened that changed everything"31. This fact was confirmed by a Kiev student. The streets of the city, according to her observation, have changed a lot that days. "Most were wearing on a soldier overcoats, or leather jackets and black caps. Many ladies stopped wearing on hats. Everyone tried to have a "democratic look". An acquaintance of one student, a resident of Kiev R., "ordered a kosovorotka (a simple shirt) for himself in a sewing workshop". Although he had ten

\footnotetext{
${ }^{27}$ Дневник и воспоминания киевской студентки (1919-1920 гг.) // Архив русской революции. Том 15. Берлин, издательство «Слово», 1924 г. - С. 217.

${ }_{28}^{28}$ Слободской А. Указ. соч. - С. 70.

29 ДАРФ, ф. 5881, оп. 2, спр. 296, арк. 6.

${ }^{30}$ ЦГАОО, ф. 5, оп. 1, д. 21, л. 28.

${ }^{31}$ Красная смута. - С. 145.
} 
suits at home, he was forced to order this satin shirt for himself. At work, he was made a reference for being "too elegant" 32 .

A special art was the ability to hide valuables so that they would not be found during a search or robbery. The owners of the house where lived the first head of the government of the Ukrainian People's Republic, V.K. Vinnichenko, in March 1918, were constantly waiting for Soviet visitors: "During the whole days has been invented ways to hide money and valuables. In pots with flowers, in a piano, in a sink tube, in a door handle, in thousands of places which were found by a tense, frightened, feverish fantasy of people who were busy only with it" ${ }^{\prime 3}$. In February 1919 , in one of the private letters abroad, an attack of robbers on the apartment of one of Kiev's families was mentioned. During the invasion, the owner of the house and her daughter were beaten, but "fortunately, not fur coats, nor Elizabeth Romanovna's diamonds were found". That means, that the most valuable objects in the apartment were hidden very safely ${ }^{34}$.

Finally, each person could and should have maximally strengthen own house. In June 1918 in Kanev V.K. Vinnichenko slowly turned his house into a "miniature fortress". The wooden boards were nailed on the windows. Vladimir Kirillovich adapted a prop to the door. The suggestion was that, if a gang of three to five people attacks, the siege can be sustained. If eight or ten people came, the only hope was "help from above, from the neighbor house". In any case, it was decided to fight to the last: "There was no point in letting gangsters come into the house without a fight, owners would be killed anyway. Now the robbery has taken a complete and decisive form: everyone is killed, whether money is found or not, all the same. Under such a condition, it was the height of frivolity to do not try at least one or two chances of salvation" 35 .

It was believed that living in large houses is always safer, but it could only be about the lesser degree of probability of an attack on your apartment. Kiev residents in May 1920, before the arrival of the Poles, were sitting at home, setting up duties in order at each entrance. Only the braves could decide to leave far to the center of the city. In the afternoon, groups of curious people were crowding at the doors, at the entrances. At

32 Дневник и воспоминания киевской студентки. - С. 227.

33 Винниченко В.К. Щоденник. Том перший. 1911-1920. Едмонтон - Нью-Йорк, 1980. - С. 313.

34 Центральний архів вищих органів влади та управління України (ЦДАВОВУ), ф. Р-2, оп. 1, спр. 343, арк. 11, 11 зв.

${ }^{35}$ Винниченко В.К. Вказ. тв. - С. 287. 
night there was absolute silence, the city seemed extinct. "The outer doors were closed tightly, and in each staircase there were such devices as logs for support, iron bars, hooks that made the house an impregnable fortress for robbers". All night inside the house behind the door were the duties, who were supposed to beat the gong in case of alarm. The night attacks usually did not happen, however, "if the robbers had taken into their minds to attack the big house, and they managed to break in, they could cut out all the inhabitants of the house with impunity. Shouts and cries would not help, lurking in hare-fear adults would sit and wait submissively for their fate" ${ }^{36}$.

When the Bolsheviks finally occupied Kiev, it seemed to the townsfolk "strange and incomprehensible" how a bunch of ragged and hungry people took the city, "where there are so many healthy, strong men, where everyone is so eagerly seeking freedom, and do not want to do anything. Power is organized, an order after order is issued. We are ready to wait, wait indefinitely, until someone - who cares - not us, will free us, ${ }^{, 37}$.

\section{Creating a self-guard}

The organization of self-defense was an attempt by peaceful urban inhabitants to protect themselves from the many dangers of that time. The composition of its groups and detachments was a cross-section of society, they consisted of representatives of all social groups.

By decision of the pedagogical councils, squads of high school students were organized at educational institutions if they voluntarily expressed a desire to take part in the internal security of the city. Along with the principle of voluntariness, the appropriate age and state of health were taken into account. Parental consent was also required ${ }^{38}$.

It was a characteristic that in the majority of gymnasiums and schools an indispensable condition for the creation of a squad of students was the obligatory presence in the classrooms and studying of squad members. In connection with the end of world war for Russia and Ukraine and the demobilization of the army, the opportunity arose for organizing the protection groups of professional soldiers. In Kharkov in January 1918,

\footnotetext{
36 Заславский Д.О. Поляки в Киеве в 1920 году. - Петроград: изд-во «Былое», 1922. - С. 11.

${ }^{37}$ Очерки жизни в Киеве в 1919-1920 гг. - С. 226.

${ }^{38}$ Вольный Юг. № 41.17 января 1918 г.
} 
according to the labor bureau, 294 representatives of such a category of citizens as former officers were looking for a work $^{39}$.

The personnel base of the self-guard detachments in the settlements and industrial enterprises of the Donetsk region and in the proletarian districts of large cities were former front-line soldiers, Red Army soldiers, mine workers, and peasant laborers. The personnel of the privately owned detachments under the hetman was very varicolored. They were students, officers, soldiers, volunteers, junkers, cadets, and even high school students ${ }^{40}$.

Officer R.B. Gul, who was in Kiev during the Hetman Skoropadsky period, joined the officer corps. The following conditions were announced: "the service is only for the protection of the city, the salary is five hundred rubles per month, there will be a hostel, food, daily allowances, and admission to the squad exempts from the general mobilization" "41. When the Germans left, the solution to the security problem was shifted to the locals. Adjutant General Grishin-Almazov, while being in November 1918 in Yalta, noted that the city is guarded by Tatar and officer detachments ${ }^{42}$.

In between 1918 and 1919, when the Volunteer Army occupied Mariupol, "a more prosperous part of the population had a desire for order and law". The city government formed a detachment of not conscripted officers to protect the order in the city. But not everywhere were involved only retired enforcement officers. According to volunteers, a "mass of a dark element spoiled in the past, under all political regimes", poured into the guard ${ }^{43}$.

To avoid aggravating the criminal situation, the volunteers tried to disarm the population, but "the guards did not take any measures to follow the order" ${ }^{\prime 4}$. In January 1919, students and Jewish teams were operating in Odessa, they were created exclusively for public protection ${ }^{45}$. Moreover, among those who signed up for those combat squads, according to white agents, "there were many names that are well known to

\footnotetext{
${ }^{39}$ Южное слово (Харьков). № 1.29 января 1918 г.

40 ДАРФ, ф. 5881, оп. 2, спр. 315, арк. 81.

${ }^{41}$ Гуль Р.Б. Киевская эпопея. // Архив русской революции. Т. 2. - М.: Современник, 1991. - С. 76.

${ }^{42}$ ЏДВА, ф. 1410, оп. 1, спр. 13, арк. 5.

${ }^{43}$ Там само, ф. 40238 , оп. 1, спр. 24, арк. 45, 46.

${ }^{44}$ Там само.

45 Гражданская война на Украине 1918-1920. Том первый, книга вторая. - С. 96.
} 
Odessa, and are known to the criminal department as robbers". The existence of such a squad could not provide peace and order $^{46}$.

In September 1919, in Kiev, according to the Soviet information, the guard of the city was carried out by "White Guard squads recruited from students, officers and sons of the bourgeoisie". The activity of these detachments was characterized as follows: "The guardians of order, often completely drunk, are scouring the city for a whole day and, especially, in the work districts, carrying out massive searches and executions" ${ }^{\prime 4}$. The White Guards considered that the involvement of only wealthy citizens in the service of protection, is justified.

On the one hand, the officials understood well who exactly would be able to actually contribute to strengthening their power, without representing a potential threat. On the other hand, the authorities were afraid of revenge from sympathizing with the Bolsheviks, including members of guerrilla groups.

There were detachments of self-organized guards on the initiative of local governments and public organizations, first of all, trade unions. In Simferopol, this issue was attended by the local city council, which, at the meeting on January 1918, discussed the issue of "introducing general duty for the protection of the city". The need for such a decision was dictated by the fact that "the external police would be abolished", the military guards were temporarily replaced by the working squads, and urgently needed to work out "a way to protect the city" 48 . Since in the cities of Crimea there were no multi-story buildings with dozens of apartments, where 30-40 people could be in the house guard, it was proposed "to unite neighboring houses into unions, and to establish not home but city quarters guards". To enhance the responsiveness to the threats that increased, it was planned to connect the houses with electrical signaling and, with its help, to provide communication with the nearest commissariats ${ }^{49}$.

In Kiev, self-protection was created everywhere in 1918, in the days of the Bolsheviks. A.A. Goldenweiser noted: "Security guards of tenants

\footnotetext{
${ }^{46}$ Гражданская война на Украине 1918-1920. Том первый, книга вторая. С. 160.

${ }^{47}$ Гражданская война на Украине. Том второй. - С. 354, 355.

${ }^{48}$ Вольный Юг. № 33. 6 января 1918 г.

49 Там же. № 40. 16 января 1918 г.
} 
who have been organized by house committees, were on duty in all houses" $" 50$.

In Kharkov, the deputy mayor turned to the residents with an appeal. Residents of each household were invited to immediately make the election of commissioners for protection, one from each household. "In view of the haste of the implementation of protection", general meetings were to be considered valid despite the number of tenants who appeared. The official expressed the conviction that citizens, "are completely understanding the importance of self-defense against banditry," would immediately implement "all Duma decrees aimed at protecting the city"

In February 1919, in the Crimea, a self-protection groups were created by the decision of meetings of local residents, although the Bolsheviks campaigned against those groups ${ }^{52}$. The residents during assemblies expressed full confidence in the self-protection organizations that were introduced by the Volunteer Army, "and decided to provide funds for its maintenance, 53 . A squad to maintain an order was also established in Yekaterinoslav, initiated by the City Duma. When the Duma inquired about the position of the squad in political matters, its leadership stated that "the function of a squad is not coups, but maintenance of order and prevention of violence against whom it should not be made - whether it is a wealthy or working class" $" 54$.

The Mariupol City Government, which, under the White Guards, replaced the City Duma, at a meeting on August 7, 1919, decided to appeal to the military authorities with a request to allow "to establish a special levy on residents of the city, to keep an additional staff of the city guard",55.

When in August 1919, white, red and UPR army were on the outskirts of Kiev, taking the fact that nobody was in the center, the criminal element rushed to rob. This time again, the chairmen of the house committees initiated to organize security. Each house has concluded an alliance with neighboring houses "in case of an attack by hooligans"

\footnotetext{
${ }^{50}$ Революция на Украине по мемуарам белых. - С. 37.

${ }^{51}$ Южный край. 26 декабря 1918 г., № 188.

52 . ЦВА, ф. 39540, оп. 1, спр. 158, арк. 23.

53 Там само, арк. 94.

54 Там само, ф. 40238, оп. 1, спр. 48, арк. 85.

55 Державний архів Донецької області (ДАДО), ф. 2568, оп. 1, спр. 4, арк. 4зв.

${ }^{56}$ Красная смута. - С. 188.
} 
In October 1919, a small detachment of civilian militia hastily organized by the city council, acted in $\mathrm{Kiev}^{57}$.

During the period of the White army staying in Ukraine, homeowners in the cities paid a fee, including payment for the night guards ${ }^{58}$. There were facts of the spontaneous formation of self-defense detachments and partisan detachments initiated by individual citizens.

The self-activity of citizens in the field of law enforcement was repeatedly manifested in Odessa. At the turn of 1918-1919, during the interventionists ruling, even special armed squads arose, which were hired "to escort the bourgeoisie from the dens to their homes at night" ". In the same place, in the beginning of 1920, when the Red Army approached, the citizens nevertheless stayed visiting clubs and theaters at night, and for returning home, they usually were gathering in groups and inviting guards, "five armed students" 60 .

Weapons for self-organized defense groups were a separate problem, although it would seem that such problems should not have existed in the country full of weapons from the front. Nevertheless, the question of the weapon supply of self-organized protective structures was decided in each case individually, based on the desired and possible. The presence in early 1918 of large number of uncontrolled weapons owned by citizens is confirmed by the fact that the authorities, with a special decision, prohibited "provocative shots to divert guards",61.

The members of self-protection squads, during the Bolsheviks period, received weapons which had been requisitioned from the bourgeois elements, and with the issuance of proper permits. On the eve of the arrival of the Germans, when the Bolsheviks already left Kiev, the weapons appeared, which the townspeople were supplied by. N.M. Mogilyansky declared: "I didn't find out who, where and why distributed it", he said. He personally saw only high school students who "ran mysteriously to Pechersk, and were dragging out new rifles, ammunition, and all kinds of military equipment". their mothers were in despair that "boys of 12-15 years of age turned their rooms either into museums or into arsenals; but the excitement of young people had no

\footnotetext{
${ }^{57}$ Революция на Украине по мемуарам белых. - С. 54.

58 ДАРФ, ф. Р-439, оп. 1, спр. 32, арк. 24.

59 Якушкин Е. Указ. соч. - С. 37.

${ }^{60}$ Тэффи Н.А. Указ. соч. - С. 331.

${ }^{61}$ Вестник Енакиево. 23(10) апреля 1918 г.
} 
bounds - everyone felt like a warrior, ready to withstand any attack, and to defend their work and their loved ones". Obviously, "they stole some armories left unguarded and unsupervised"62.

Under the hetman, the processes of disarming the population ${ }^{63}$ and the arming of the "trustworthy population" took place at the same time with the process of successful formation of a "privately owned guard" 64 . In Kharkov, after Petliurists left, the energetic measures were taken to preserve some of the weapons left by the entire guard force in the abandoned sections ${ }^{65}$.

After the end of fightings on the territory of Ukraine began the disarmament of the population. To stimulate this process, the authorities offered money. For a serviceable trilinear, it was supposed to be payed eight hundred rubles, for those in need of repair, or a foreign one - five hundred. No documents were required ${ }^{66}$. Many partisans themselves came to the police handing over their weapons ${ }^{67}$.

\section{Self-protection activities}

Contradictory opinions were expressed about its effectiveness, mostly skeptical at the beginning of the revolution. The first doubts appeared during the process of replacing the old police with the militia. The correspondent of the "Odessa leaflet" ironically asked in March 1917: "Is it possible to compare a police officer who can give a certain resistance to all sorts of suspicious elements, with some skinny policeman, student or worker, without any experience, skill, etc." ${ }^{\prime 68}$.

Law enforcement professionals were wary of amateur assistants. In September 1917, the head of the Kiev police considered it inappropriate to create "order of guards", preferring to him the formation of an additional police force, "especially equestrian". The chief recklessly declared: "There is no any expectations of great disturbances in the city now, there is no reason for them" ${ }^{\prime \prime}$.

\footnotetext{
621918 год на Украине. - С. 35.

${ }^{63}$ ЦДАВОВУ, ф. 1216, оп. 1, спр. 2, арк. 54зв.

64 Там само, арк. 74.

${ }^{65}$ Южный край. 2 января 1919 г., № 2.

${ }^{66}$ Гражданская война на Украине. Том третий. - С. 441.

67 Державний архів Харківської області, ф. Р-202, оп. 2, спр. 6c, арк. 45.

${ }^{68}$ Одесский листок, 4 (17) марта 1917 г.

${ }^{69}$ Киевская мысль. № 105. 27 сентября 1917 г.
} 
Life forced the most peaceful citizens to organize. S. Sumsky recalled the events in Kiev in January 1918: "The night duty took place in the courtyard. Four men were going down every three hours. Silently, the attendants walked around the yard and listened to a rare shot or a break" ${ }^{, 70}$. But, in general, such duty helped a little. A. Goldenweiser noted: "The last nights, as usual before the change of power, were quite disturbing. The number of raids happened" "71 . During the short stay of the Bolsheviks, under the pretext of searching private houses, the usual thieves were coming in to steal. "In order to distinguish pseudo detective agents from real ones", the bourgeoisie, with the help of the already existing house committees, organized a night duties, in which women participated on an equal basis with men, and often thieves who had been caught on time, fled without causing any harm. "Sometimes they even managed to arrest thieves with the help of the militia, who were called up on time by telephone. Thus, the bourgeoisie actually learned the benefits of organization, the unity". Representatives of the lower strata almost never took part in the duties. "It seemed that they found some malicious pleasure to see the girls and ladies from high class walking in the frosty snow all night". Small traders and craftsmen were also suffered from these nightly attacks, and many shops and workshops had been robbed at that time ${ }^{72}$.

V.I. Vernadsky pointed out that during the Bolsheviks, selfprotection was disarmed, which made the residents nervous. He felt that he was captured by the "disgusting feeling of complete powerlessness and complete insecurity in the future, not for himself, but for his relatives there were possibilities of the most terrible tests for them due to preventing the organization of self-defense" ${ }^{, 73}$. According to the testimony of the museum worker N.M. Mogilyansky, before the arrival of the Germans, only when the Bolsheviks left the city, the organization of selfdefense began.

This time was remembered by the citizens of Kiev as "absolutely horrible". In one of the last nights before the Germans arrived to Kiev, there were 176 attacks on the inhabitants' apartments. It was difficult to

\footnotetext{
${ }^{70}$ Революция на Украине по мемуарам белых. - С. 104.

${ }^{71}$ Революция на Украине по мемуарам белых. - С. 37.

72 Лейхтенбергский Г.Н. Воспоминания об «Украине». 1917-1918. Берлин: к-во «Детинец», 1921. - С. 23.

${ }^{73}$ Вернадський В.И. Вказ. тв. - С. 54.
} 
organize the protection. Were elected the House committees, who started the organization of self-defense. "And now people, who did not carry guns in their lives, sometimes honored, gray-haired Kievans, began to clean and repair guns, and to discuss strategic methods to protect houses and estates from the attacks of robbers". In some places, officers appeared who were responsible for the organization of defense and to order over the home military brigades. House number 22 , which was commanded by a personnel officer, became the center for protection of several houses on its site. A field telephone appeared here, uniting six neighboring detachments, obliged to appear to a threatened place on the first call ${ }^{74}$.

In March 1918, the home security in Kharkov was organized almost everywhere, and at night guards were on duty at the gates and porches of houses. House security was characterized by poor organization and the absence of weapons, which did not allow the real resistance to robbery attempts. In most cases, house guards were a kind of "a self-consolation, or even a home entertainment, it was good that leaving the house at night was forbidden". So, in order to not waist their time, guards were putting the table on the stairs and the card game began. Young people had fun by flirting. In the areas where the Red Army soldiers lived, the self-defense guards managed to prevent looting by alarming on time, and soldiers resorted to the raised alarm with riffles ${ }^{75}$. Thus, even in this case, we are not talking about clashes with criminals, but rather about the psychological impact.

The establishment of the regime of Hetman Skoropadsky led to a reduction in crime, but did not rule out the existence of self-organized law enforcement agencies. Thus, an order was established everywhere in one of the districts of Kharkov, which was maintained by the population itself, who were transferring its violators to the hands of justice ${ }^{76}$. The Odessans in May 1918 optimistically believed that "the Bolshevik's horrors has been left in the past". On the central streets were "brave militiamen"77. Nevertheless, the criminal elements were far from being neutralized; disarmament was not carried out fast enough. "There have been cases when the Austrians themselves advised to hide the weapon, saying that it may be needed soon". Along with it, the weapon supply to the trustworthy

\footnotetext{
741918 год на Украине. - С. 36.

75 Южное слово (Харьков). № 4.17 марта 1918 г.

${ }^{76}$ Возрождение (Харьков). № 58. 30 мая 1918 г.

${ }^{77}$ Южная заря (Екатеринослав). № 2. 10 мая 1918 г.
} 
part of the population was difficult ${ }^{78}$. For the protection of the order, besides the guards, volunteer squads were organized, but, "hastily formed, poorly armed and trained, they did not represent a serious force" ${ }^{\text {"79 }}$. Even representatives of the Volunteer Army recognized, that the order of public life in Ukraine after arrival of the Germans and their providing of guarantees of personal and property safety, was adjusted ${ }^{80}$.

One privately owned detachment's commander, who had documents of the lieutenant, with the aim of forcing the owner to increase his salary, repeatedly filed various protests. One time it was about a bad accommodation, another- about an unsatisfactory food. To show the particular danger of his service, the lieutenant even twice faked with an attack by his own people on the estate, which, of course, fought off with complete success ${ }^{81}$.

Towns on the border were engaged in the transportation of refugees across the border. There were many private houses that turned into inns. The owners were taking high prices from guests, and could recommend carters who knew how to get past the Bolsheviks. There were professionals who were organizing the moving under the protection of sailors who accompanied the wagons ${ }^{82}$.

In Kiev, before the arrival of the Petliurists, there was an anarchy. This period lasted a whole week. "The guards of the tenants were functioning in all the houses, but, as always, they were completely powerless" $"$.

In 1919, while the White Guard troops were staying in the region, the local administration used employees of the city and industrial county guards to try to resist Bolshevik's agitation, and to detain the Bolsheviks $^{84}$. It is characteristic that the actions of the partisan detachments did not create particular problems for law enforcement agencies. Thus, in one of the circulars, it was noted that in some areas "armed gangs are hiding", and officers related to this fact "absolutely indifferent" ${ }^{\text {"55 }}$. However, "illegal armed groups" posed a constant threat to

${ }_{78}$ ДАРФ, ф. Р-446, оп. 1, спр. 15, арк. 23в.

79 Там само, арк. 3 .

${ }^{80}$ ДАРФ, ф. Р-439, оп. 1, спр. 108, арк. 29.

81 Там само, ф. 5881, оп. 2, спр. 315, арк. 83.

82 Из путевых заметок беженца. Кн. Е.Н. Трубецкого // Архив русской революции. Том 18. Берлин, издательство «Слово», 1926 г. - С. 139.

${ }^{83}$ Революция на Украине по мемуарам белых. - С. 51.

${ }^{84}$ ДАДО, ф. 2559, оп. 1, спр. 1, арк. 15.

85 Там само, арк. 19. 
financial institutions. It can be assumed that on the eve of the days of salary payment, the activity of illegal associations were increasing markedly. To prevent the attempts of robberies, the bailiffs of the respective areas were ordered to have a sufficient guard for 24 hours at all mine and factory cash desks ${ }^{86}$.

Under the rule of Denikin, only proprietors and students were taken into self-protection, but usually they didn't want to take up weapons, "preferring to pay off". The state guard did not represent real strength; they were running away after first $\operatorname{shot}^{87}$. There were quite a lot of partisan detachments, but they had no definite goals, "except for looting" $"$. The local self-defense of Kiev, organized by "someone from Kiev socialists to protect residents from robberies", were wearing a white band on their sleeves as a distinguishing mark $^{89}$. Sometimes selfprotection was quite successful. The head of one of the counties reported to the Yekaterinoslav governor in November 1919 that a group of bandits was arrested with the help of the self-guard detachment. "One of the leaders has been wounded and sent to the district hospital. weapons and bombs has been found" $"$.

One of the most common methods of protection for individual houses was to place several armed people there. So, the owner of one of the Kiev hotels, "very good and large", gave a room for the guardians and, moreover, provided them tea and bread. "Thanks to such cooperation, the owner was somehow and for some time protected from the robbery" $"$.

In the spring of 1920 in Odessa, in addition to military units, workers' detachments were scattered throughout the city. By that time, workers' squads, which were located at the police stations, were organized. At night there were patrols, bypassing the neighborhoods entrusted to their guard ${ }^{92}$.

Kiev before the arrival of the Poles once again found itself without ruling power. As always in such cases, some unknown young people with arm bands appeared on the city streets. Whether they were robbing, or defending from robbers, nobody knew exactly. People said that "there are

\footnotetext{
${ }^{86}$ ДАДО, ф. 2559, оп. 1, спр. 1, арк. 17.

${ }^{87}$ РДАСПІ, ф. 71, оп. 34, спр. 1285, арк. 19.

${ }^{88}$ Там само, арк. 20.

${ }^{89}$ Красная смута. - С. 190.

90 ДАДО, ф. 2559, оп. 1, спр. 2, арк. 24.

91 Красная смута. - С. 275.

92 ДАРФ, ф. 5881, оп. 1, спр. 704, арк. 11.
} 
real guards who protect, and fake ones who rob". It was possible to get help on this issue "calling on the not-working phone in some institution", which also sometimes turned out to be fake. The best way out was to stay away from "young people with bands" " This time, the Georgian squad appeared "unchangeable with all changes of power". There were about twenty of them - "seems all students". During the previous coups, Jewish self-defense group has been organized, but this time "there was no aspiration and no strength to repeat such an experience" $"$.

When Yekaterinoslav was occupied by the Reds, they made an unusually disciplined impression on the inhabitants. After several very quiet days, the population "began to bless the Soviet regime, which put the end to its natural state" 95 .

The end of fights on the main territory of Ukraine set before the Soviets the task of restoring order after years of war. The organization of the militia, either for hire or on a voluntary basis, took place ${ }^{96}$. The fight against robberies, extortion, requisitions, confiscations and other things began again. Such an actions, as well as searches and arrests, were forbidden to be performed only if it was done without the knowledge of the revolutionary committees, however with their permission the same actions became quite common ${ }^{97}$.

\section{CONCLUSIONS}

Thus, the provision of the public order in the cities of Ukraine in 1917-1920 was one of the most important tasks that were solved at this period at different levels. All governments that exercised their authority on the territory of Ukraine, by all means, tried to restore order, prohibited robberies camouflaged under requisition.

The history of self-organized protection in Ukraine has a clear chronological framework. It began in the summer and autumn of 1917, when the weakness of the Provisional Government led, among other things, to a deterioration in the criminal situation in the country. In 1917 and early 1918, self-protection was often an auxiliary force to assist law enforcement agencies during deep crisis. In 1918, with the strengthening

\footnotetext{
93 Очерки жизни в Киеве в 1919-1920 гг. - С. 226.

94 Заславский Д.О. Указ. соч. - С. 12.

95 Революция на Украине по мемуарам белых. - С. 194.

96 Державний архів Луганської області (ДАЛО), ф. Р-1173, оп. 1, спр. 3, арк. 8.

${ }^{97}$ Там само, арк. 4зв.
} 
of Ukrainian statehood, law enforcement agencies established a relative order in the country, however, self-protection groups continued to perform their functions as an additional organizations to ensure stability. In 1919 the beginning of 1920, self-protection repeatedly became the only opportunity for ordinary citizens to defend themselves against the vicissitudes of civil war. The activities of self-defense groups were stopped in the late 1920s and early 1921, at the same time with the strengthening of the official law enforcement structures - the militia, the Cheka, etc. In most parts of Ukraine, Soviet power was finally established, and self-protection gradually lost its meaning.

During the mentioned time, the self-defense units either operated in parallel with the bodies that were considered state bodies at that time, or functioned independently in some regions. The emergence and activity of overlapping law enforcement structures created a certain tension between them, sometimes leading to direct clashes. The local population was ready to bear the material costs to have at least a relative safety. Practically with any authority, self-protection was self-financing, that is, it was operated at the expense of citizens. Acquisition of security was carried out in various ways. First, security functions were performed in turn by residents of houses. Secondly, labor collectives were nominating their most reputable representatives to protect. Thirdly, periodic mobilizations has been carried out, either by the authorities or by self-appointed initiators. Finally, there were squads that formed on the principle of voluntariness.

The composition of guards depended on the kind of power. The Soviet institutions preferred to involve former front-line soldiers, workers - most of all miners and metallurgists, and the poorest farm laborers who had previously worked for hire. The White Guards sought to rely on small and medium-sized owners living in the cities or villages homeowners, merchants, wealthy peasants. Groups and detachments of law enforcement also included retired officers, students, high-school students, intellectuals, declassed elements, and former prisoners. Central authorities, local governments, political and public organizations, and house committees were creating a security. On the territories, where the population was mainly engaged in industrial work, self-protection was created at mines and factories, in the countryside - by a common peasant meetings.

When the authorities changed, the previous guards never continued official activities. It either voluntarily diverged, and the former guards 
replenished regular military units, or switched to the illegal status as a partisan struggle.

Methods of weapons supply were also very diverse. Local councils or army units could help with weapons, or it was confiscated from social enemies or invaders. Usual hunting rifles were used. The documents do not contain information about the usage of weapons brought by former soldiers. Indirectly, people had an evidence of its presence, and authorities were simultaneously trying to fight with uncontrolled possession of weapons with very tough methods, at the same time arming the guards.

Self-defense organizations performed numerous functions, which included the fights against speculation, ensuring discipline at public events, protecting their living places from thugs (whether reds, or whites, or even greens), detaining opponents of existing power, suppressing social unrest and crashes, etc.

Security was provided at the level of the city, district, quarter, separate house. The security was hired by both homeowners and ordinary citizens. Security was always created in response to the heightened threat of criminal encroachment, but never in advance. The effectiveness of "homegrown" security, was rather low due to the lack of weapons, lack of training, and lack of relevant experience. Her actual weakness in the face of real danger was emphasized by most witnesses. The only exceptions were the Red Guard units in the workers' districts. The low fighting qualities of protection were explained by the fact that both robbing and protection of the population were performed by the representatives of the same social groups, and sometimes by the same people. In general, the organization of self-protection, supported both from the top and from the bottom, became a natural, expected reaction of society to the growth of anarchy and, despite numerous costs, brought serious positive results.

Such a social phenomenon as the creation of protection by residents of individual houses, workers' enterprises and residents of settlements, which took place in different regions of Ukraine during the revolution and civil war of 1917-1920, served as a vivid evidence of the ability of society to organize itself under extreme conditions.

\section{SUMMARY}

The beginning of history of self-protection in Ukraine falls on the summer-autumn of 1917, when the criminal situation in the country worsened. In 1919 - the beginning of 1920, self-protection was often the 
only way for ordinary citizens to defend themselves against the vicissitudes of the Civil War.

Self-defense detachments either operated in parallel with the bodies that were considered state authorities at the time, or functioned autonomously in some regions. Practically with any authority, selfprotection was self-financed, i.e. it operated at the expense of citizens. Formation of guard detachments was carried out in various ways, its composition depended on the nature of power, the ways of arming were also varied.

Self-defense performed numerous functions, which include the fight against speculation, ensuring discipline at public events, protecting their localities from bandits, detaining opponents of the existing government, riot control, suppressing pogroms. This social phenomenon served as vivid evidence of the ability of society to self-organize in extreme conditions.

\section{REFERENCES}

1. Вернадський В. І. Щоденники (1917-1921) / В. І. Вернадський // Вибрані наук. праці акад. В. І. Вернадського. - К. : НАНУ, 2011. Том 9. $-326 \mathrm{c}$.

2. Винниченко В. К. Щоденник / В. К. Винниченко. - Едмонтон Нью-Йорк, 1980. - Том перший. 1911-1920. - 500 с. - (Видання Канадського Інституту Українських Студій і Комісії УВАН у США для вивчення і публікації спадщини Володимира Винниченка).

3. Гольденвейзер А. А. Из киевских воспоминаний / А. А. Гольденвейзер // Архив русской революции / [изданный Г. В. Гессеном]. - М. : Терра-Политиздат, 1991. - Т. 6. - 364 с.

4. Гуль Р. Б. Киевская эпопея (ноябрь-декабрь 1918 г.) / Р. Б. Гуль // Архив русской революции / [сост. И. В. Гессен]. - М. : Современник, 1991. - Т. 2. - 288 с.

5. Дневник и воспоминания киевской студентки $(1919-1920$ гг.) // Архив русской революции / [изд. Г. В. Гессеном]. - Берлин : Изд-во «Слово», 1924. - Т. 15. - 345 с.

6. Заславский Д. О. Поляки в Киеве в 1920 году / Д. О. Заславский. - Петроград : Изд-во «Былое», 1922. - 48 с.

7. Игренев Г. Екатеринославские воспоминания (август 1918 июнь 1919 г.) / Г. Игренев // Архив русской революции / [изданный Г. В. Гессеном]. - М. : Терра-Политиздат, 1991. - Т. 3. - 274 с. 
8. Корсак В. В. (Завадский). У красных. У белых. Великий исход / В. В. Корсак // Красная смута: сб. ист. лит. произв. / [сост. Р. Г. Гагкуев]. - М. : Содружество «Посев», 2011. - 624 с.

9. Лейхтенбергский Г. Н. Воспоминания об «Украине». 19171918 / Г.Н.Лейхтенбергский ; [авторизованный пер. с франц.]. Берлин : Детинец, 1921. - 52 с.

10. Могилянский Н. Н. Трагедия Украины (из пережитого в Киеве в 1918 году) / Н. Н. Могилянский // 1918 год на Украине. Серия «Россия забытая и неизвестная. Белое движение». - М.: Центрполиграф, 2001. - 414 с.

11. Оболенский В. Крым при Врангеле. Мемуары белогвардейца / В. Оболенский. - М.-Л. : Гос. изд-во, 1927. - 86 с.

12. Очерки жизни в Киеве в 1919-1920 гг. // Архив русской революции / [изданный Г. В. Гессеном]. - М. : Терра-Политиздат, 1991. - T. 3. - 274 c.

13. Революция на Украине по мемуарам белых / Сост. С. А. Алексеев, под редакцией Н. Н. Попова. - Москва-Ленинград: Государственное издательство., 1930 г. Репринтное воспроизведение издания 1930 г. Киев: Политиздат, 1990 г. - 436 с.

14. Слободской А. Это было... (на Украине и в Крыму в 19181920 гг.) / А. Слободской. - Харьков : Пролетарий, 1926. - 102 с.

15. Трубецкой Е. Н. Из путевых заметок беженца Е. Н. Трубецкой // Архив русской революции / [изданный Г. В. Гессеном]. - Берлин : Изд-во «Слово», 1926. - Т. 18. - 319 с.

16. Тэффи Н. А. Житье-бытье: Рассказы. Воспоминания / Н. А. Тэффи. - М. : Политиздат, 1991. - 445 с.

17. Українська Центральна Рада. Документи i матеріали : у 2-х тт. - К. : Наук. думка, 1996. - Том 1. 4 березня - 9 грудня 1917 p. -588 c.

18. Якушкин Е. Французская интервенция на Юге. 1918-1919 / Е. Якушкин. - М.-Л. : Гос. изд-во, 1929. - 80 с.

\section{Information about the authors:}

Popov V. Z.

Dr. History Sciences, Professor V.I. Vernadsky Taurida National University 01133, Ukraine, Kyiv, 33 Ivana Kudry Str. 